\title{
EFFECTS OF TIRE CHIPS ON THE SHRINKAGE AND CRACKING CHARACTERISTICS OF CLAYEY SOILS
}

\author{
VPLIV DROBCEV PNEVMATIKE NA SKRČEK IN POKANJE \\ GLINENE ZEMLJINE
}

\author{
Niyazi Uğur Terzi ${ }^{1}$, Mürüvet Ünlü Özsoy ${ }^{1}$, Ferruh Yilmaztürk $^{2}$, Bahattin Güllï̈ ${ }^{3}$, \\ Can Erenson ${ }^{1}$ \\ ${ }^{1}$ Aksaray University, Department of Civil Engineering, 68100 Aksaray, Turkey \\ ${ }^{2}$ Aksaray University, Department of Geomatic Engineering, 68100 Aksaray, Turkey \\ ${ }^{3}$ Aksaray University, Department of Geology Engineering, 68100 Aksaray, Turkey \\ niyaziterzi@gmail.com \\ Prejem rokopisa - received: 2017-05-16; sprejem za objavo - accepted for publication: 2017-08-11
}

doi:10.17222/mit.2017.057

\begin{abstract}
Desiccation can be heavily detrimental and can adversely influence the performance of clayey soils in various engineering applications such as compacted clay barriers in waste containments, dam cores, canal liners, and road pavements. Cracks may affect the compressibility of soil, its rate of consolidation, its strength and the permeability rate, at which water can re-enter the soil. In this study, we attempted to utilize tire monofilaments as the additive material to improve the anti-cracking properties of compacted clay. To characterize crack patterns quantitatively, close-range digital-image-analysis techniques were used to analyze the desiccation generation and propagation. The results show that there is a definite improvement in the cracking characteristics of the clay material when it is mixed with tire monofilaments.

Keywords: intensity factor, drying shrinkage, desiccation cracking, image processing
\end{abstract}

Sušenje je lahko zelo škodljivo in ima neugoden vpliv na glineno zemljino v različnih inženirskih aplikacijah, kot so: kompaktne glinene ovire v zadrževalnikih odpadkov, jedru nasipov, prekopih in cestnih pločnikih. Razpoke lahko vplivajo na stisljivost zemljine, njeno hitrost konsolidacije, trdnost in prepustnost za vodo. V prispevku avtorji opisujejo študijo uporabe drobcev pnevmatik kot dodatek, ki naj bi izboljšal odpornost proti pokanju kompaktirane zemljine. Za to, da bi kvantitativno okarakterizirali vzorce razpok, sušenje zemljine in napredovanje razpok so uporabili digitalno analizo slike. Rezultati študije so pokazali nedvomno izboljšanje odpornosti zemljine proti pokanju, če so bili glinenemu materialu dodani drobci oziroma vlakna pnevmatik.

Ključne besede: faktor intenzitete, skrček med sušenjem, pokanje zaradi sušenja, obdelava slike

\section{INTRODUCTION}

Desiccation cracking may be perceived as a two-fold process that entails a gradual loss of moisture from an initially saturated porous body. ${ }^{1}$ It is commonly known that desiccation clay soils crack when the tensile stress develops in the soil due to the matric-soil suction exceeding the tensile strength of the soil. Tensile stresses only develop when the soil is, in some way, restrained against shrinkage. The restraint can be external such as a rough layer interface or internal; for example, sections of soil undergoing non-uniform drying. The causes of cracking could be either a volumetric change in the soil body or a consequence of the pressure exerted on the soil body. In line with the formation system, M. H. Maher and D. H. Gray ${ }^{2}$ categorized the following two major types of cracks:

- Mechanical cracks, which are formed via a deposition or due to an inappropriate construction. A good example is cracks without a good linkage between lifts and with poor compaction.

- Physicochemical cracks, which can be subdivided into these three categories: cracks caused by syne- resis, cracks caused by freeze-thaw cycles, and cracks initiated by thorough drying of the material.

The most important crack category is the drying process of the soil. The desiccation of an initially saturated soil usually involves a gradual reduction in the moisture content induced by evaporation from the soil surface. The drying process can result in the development of capillary suction in the upper layer because of the effects of the meniscus surface tension. The suction creates a new arrangement of soil particles and some portions of the material tend to shrink. As a result, considering the scale of particles and their interactions within the soil surface layer, the particles undergo tensile stresses attributable to the pore-fluid modulated movement of the surrounding soil particles. This process increases the horizontal tensile-stress field in the upper layer of specimens during drying.

Tensile stresses increase as the water evaporation proceeds. ${ }^{3}$ In other words, the desiccation cracks are primarily influenced by soil suction and tensile strength. Thus, soil suction is the mechanical initiator of the cracking process. The other main factors that influence the shrinkage cracking activities of fine-grained soils in- 
clude clay mineralogy, activity and content, compaction conditions, the drying process, wetting/drying cycles, soil-particle orientation, unit weight, pore fluid, and exchangeable ions. ${ }^{4}$ The probability of shrinkage and swelling increases when the plasticity index of the clay increases. However, the danger of shrinkage and cracking can be minimized by fortifying clay soil with coarse-grained materials. ${ }^{5}$

For the fabrication of a liner in arid sites, D. E. Daniel and $\mathrm{Y} . \mathrm{K}$. $\mathrm{Wu}^{6}$ suggested the use of clayey sand with a low hydraulic conductivity and low shrinkage values. Besides, C. H. Benson and S. R. Meer ${ }^{7}$ and F. Mazzieri ${ }^{8}$ examined the influence of wet-dry cycling on the swelling and $k$ behavior of GCL. The results of hydraulic-conductivity tests carried out by B. A. Albrecht and C. H. Benson ${ }^{9}$ on compacted and saturated soils during wetting/drying cycles showed that the shrinkage strain is directly proportional to the compaction effort and closeness to the optimum water content. The restriction of pressure is also a major factor in the cracking phenomena. ${ }^{10} \mathrm{~K}$. J. Witt and R. M. Zeh ${ }^{11}$ examined cracks associated with desiccation of the cover lining system and design strategies. H. Krisdani et al. ${ }^{12}$ studied the effects of drying rates on the shrinkage characteristics of the residual soil obtained from the Bukit Timah granite (Singapore) and mixtures of the residual soil and fine sand. The results of the shrinkage test showed that drying rates affected the speed of the change in the void ratio and the degree of saturation changes in the soil. Finally, according to the results obtained by G. H. Omi$\mathrm{di}^{13}$, K. J. Osinubi and A. O. Eberemu ${ }^{14}$, T. Harianto et al. ${ }^{15}$ and N. Talluri et al. ${ }^{16}$, the shrinkage strain depends on three main parameters, the mold-water content, the dry density (compaction effort) and the soil-plasticity index.

Based on the research given above, considerable work was undertaken to investigate soil treatment to prevent desiccation cracks. There are different types of treatments comprising traditional additives including cement, lime, fly ash and new materials such as fiber. The study conducted by Y. Guney et al. ${ }^{17}$ on the impact of cyclic wetting-drying on the swelling behavior of lime-stabilized soil showed that lime-stabilized soils are negatively affected by the wetting/drying cycles. The treatment materials were mostly lime, cement and fly-ash mixtures used for the crack prevention. However, they found that the additives of lime and cement used to improve the resistance to desiccation were not effective for treating liners. In addition, alternative laboratory approaches to cyclic permeation-desiccation experiments on specimens of geosynthetic clay liners (GCL) were compared by F. Zangl and W. J. Likos. ${ }^{18}$ They observed that their similarity indicates internal flaws in the bentonite (e.g., reinforcing fibers), rather than external stress conditions, preventing desiccation-crack initiation and propagation. According to B. A. Maher et al., ${ }^{19}$ M. S. Nataraj and K. L. McManis ${ }^{20}$ and C. S. Tang et al., ${ }^{21}$ one of the best materials for preventing cracks is fiber. They stated that an amount of fibers in a clay liner results in a great reduction in the value of the crack-intensity factor. Thus, in the current study, we report on our investigation into the use of waste-tire chips as a source of fibers for the prevention of desiccation cracks. The additive material consisted of straw-shredded tire granules cut into monofilament-fiber shapes used to improve the anti-cracking properties of the clay material. The cracking properties and crack nucleation of each composite liner specimen were compared with digital images. The decreasing of the soil-water content, drying shrinkage, crack initiation and propagation were monitored using an image-processing technique. The geometric and kinematic characteristics of the surface crack pattern obtained from the crack-intensity factor (CIF) and crack-reduction factor (CR) are described.

\section{EXPERIMENTAL PART}

The testing procedure consisted of three main steps: preparing composite-mixture specimens, drying the specimens, obtaining images of cracks using close-range digital-image-analysis techniques and a quantitative analysis of the cracks. The tire-monofilament materials were mixed with clayey soil at five different ratios.

After the preparation of the specimens, all the soil samples were wetted with the targeted moisture content. The prepared clay composite mixtures were placed in polythene bags and sealed to prevent moisture leakage. The samples were prepared manually and placed into Plexiglas molds with dimensions of $(30 \times 60 \times 8) \mathrm{cm}$ using a spatula. In order to observe the shrinkage and crack propagation, the samples were kept in a wellventilated room to be air dried. The specimens were weighed four times a day using a digital electronic balance. The room temperature and relative humidity were also recorded with a humidity-temperature data logger. The surface geometric features of the cracks that developed due to the wetting/drying cycles were monitored using image-processing techniques and a CCD digital camera (a lens of 12/120 mm) was used to visually assess the extent of the cracking and the decrease in the water content due to evaporation. The camera was fixed at a height of $50 \mathrm{~cm}$ above the top surface of the soil specimens. A specially designed tripod set-up was used to ensure that all the close-range images were obtained from the same height. All the measurements and images were taken $6 \mathrm{~d}$ after the day when the specimens were prepared. The visual observations of the desiccation-cracking process were quantified using CIF and CR in the MATLAB program. 
Table 1: Geochemical-analysis results for the Avanos-clay samples

\begin{tabular}{|c|c|c|c|c|c|c|c|c|c|c|c|c|c|c|c|}
\hline Element & $\mathrm{Na}_{2} \mathrm{O}$ & $\mathrm{MgO}$ & $\mathrm{Al}_{2} \mathrm{O}_{3}$ & $\mathrm{SiO}_{2}$ & $\mathrm{P}_{2} \mathrm{O}_{5}$ & $\mathrm{SO} 4$ & $\mathrm{~K}_{2} \mathrm{O}$ & $\mathrm{CaO}$ & $\mathrm{TiO}_{2}$ & $\mathrm{MnO}$ & $\mathrm{Fe}_{2} \mathrm{O}_{3}$ & $\mathrm{Cl}$ & LOI & Total \\
\hline Dimension & \multicolumn{10}{|c|}{$\%$} \\
\hline Clay1 & 0.371 & 2.103 & 17.098 & 38.481 & 0.105 & 0.178 & 4.565 & 5.691 & 0.425 & 0.133 & 7.988 & 0.055 & 21.8 & 99.09 \\
\hline Element & $\mathrm{Ba}$ & $\mathrm{V}$ & $\mathrm{Ni}$ & $\mathrm{Zn}$ & $\mathrm{As}$ & $\mathrm{Pb}$ & $\mathrm{Ce}$ & $\mathrm{Cr}$ & $\mathrm{Cu}$ & $\mathrm{Ga}$ & $\mathrm{Rb}$ & $\mathrm{Sr}$ & $\mathrm{Y}$ & $\mathrm{Zr}$ \\
\hline Dimension & $\%$ & \multicolumn{10}{|c|}{$\mu \mathrm{g} / \mathrm{g}$} \\
\hline Clay1 & 0.098 & 113.1 & 89.3 & 106 & 152.2 & 61 & 270.8 & 112.1 & 94.1 & 37.5 & 223.5 & 499.7 & 29.8 & 108.7 \\
\hline
\end{tabular}

\subsection{Material properties}

\subsubsection{Physical, mineralogical and geochemical charac-} teristics of the Avanos clay

The Kizilirmak clayey soil from the Avanos delta in Central Anatolia was selected for the investigation. The samples were obtained from a depth of 3-5 $\mathrm{m}$ from the surface. The soil was classified as inorganic and plastic clay and the basic properties of the liquid limit, plastic limit, plasticity index, linear shrinkage and volumetric shrinkage were $(55,36,19,14.8$ and 16.45$) \%$ respectively. To determine the mineralogical composition of the Avanos clay, an X-ray diffraction (XRD) analysis was carried out at the Earth Science Application \& Research Center at the Ankara University using an Inel Equinox 1000 device with a cobalt (Co-A1) tube with a wavelength of $(\lambda=0.1788970 \mathrm{~nm})$ as the X-ray source. The clay sample was crushed with a tungsten carbide grinder to a 200 -mesh (20 micron) size. The resulting peaks from the analysis were evaluated in the "search-match" program. The results revealed that the Avanos clay contains quartz, calcite, hematite, biotite and clay minerals comprising montmorillonite, kaolinite and illite (Figure 1). A wavelength-dispersive X-ray fluorescence (WD-XRF) analysis was performed to compare the chemical and mineralogical composition of the Avanos clay. The analysis was carried out in the geochemical laboratory of the Aksaray University, the Faculty of Engineering, the Geological Engineering Department. The results of the geochemical analysis of the Avanos-clay samples are given in Table $\mathbf{1}$.

The geochemical analysis reveals that the main elements of the Avanos clay are oxides $\mathrm{SiO}_{2}, \mathrm{Al}_{2} \mathrm{O}_{3}$, $\mathrm{Fe}_{2} \mathrm{O}_{3}$ and $\mathrm{CaO}$, with the $\mathrm{K}_{2} \mathrm{O}$ elements being dominant. The comparison of the XRD analysis with the results of the geochemical analysis shows that the $\mathrm{SiO}_{2}$ content can

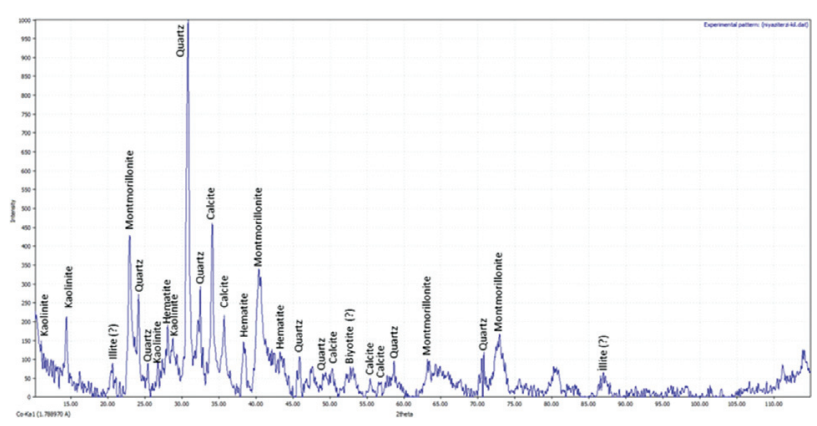

Figure 1: The mineralogical composition of the Avanos Clay be associated with free quartz and silicate compounds in the samples. It was found that the clay is rich in smectite minerals, which make the soil highly water absorbent, resulting in an expansion of the material. These kinds of soil show a significant change in the volume during drying. These minerals play the central role in creating the properties of the soil, such as plasticity and strength. As expected, when the water content of the clayey soil decreases or increases, the soil shrinks or swells. This may cause soil damage ranging from small hairline cracks to a serious structural distress. It is therefore important to study the shrinkage properties of clay. The Avanos Kizilirmak specimen used for the volumetricshrinkage test (Figure 2), was prepared according to BS 1377. Based on the standards, the specimen weight was measured periodically and external dimensions were

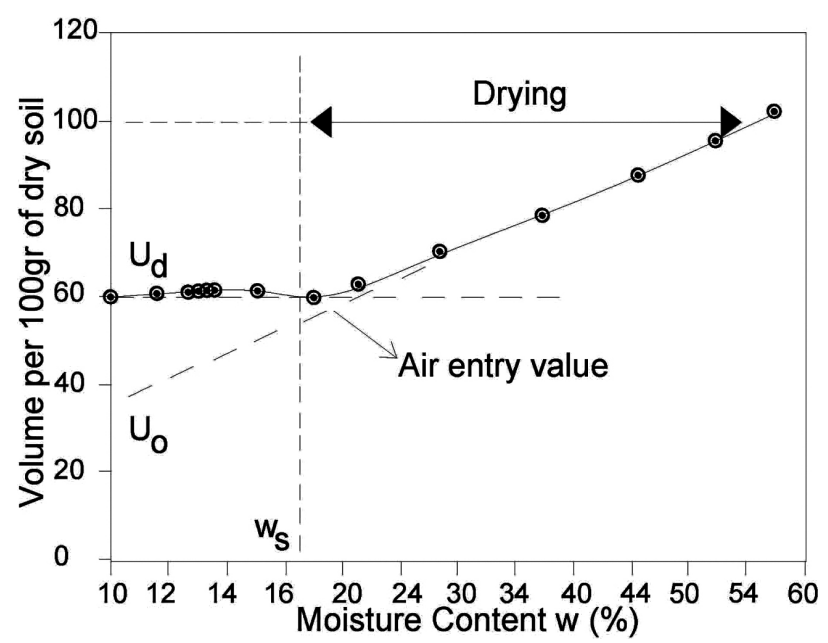

Figure 2: Shrinkage curve for Avanos solo clay

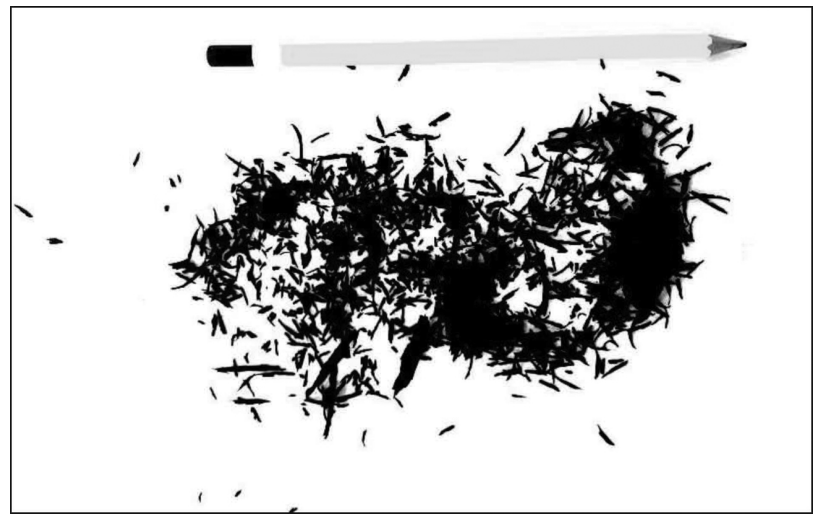

Figure 3: Tire monofilaments 


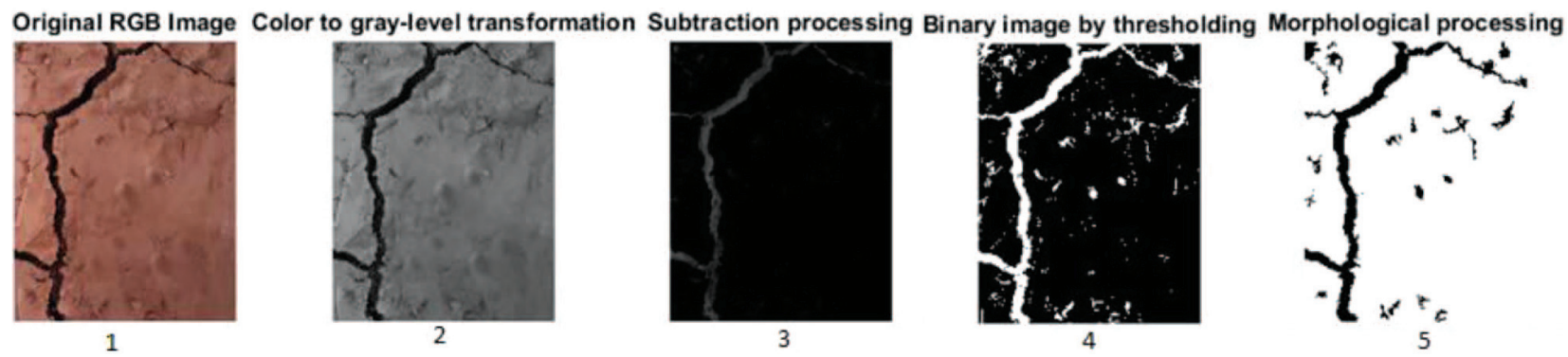

Figure 4: Result of the proposed image processing

2) cracks are usually continuous within a certain neighborhood, that is, crack pixels are connected with each other to form curves rather than being isolated.

These assumptions are true for 2D intensity images and two primitive crack-segmentation approaches used in ${ }^{26}$ were based on this thresholding and edge detection. The core logic of thresholding methods is to compare each pixel to its neighborhood; if the value of a pixel is significantly lower, then it is determined to be a crack pixel. Our approach to extracting crack information is based on the thresholding assumption. The image-processing steps that we applied to detect cracks consist of the following procedures:

1) the transformation of the acquired digital color image into a gray-level image;

2) an improved subtraction method for the image in uniform brightness;

3) binarization; and

4) morphological processing using erosion and dilation.

Figure 4 shows the result of the whole image processing from the gray-level transformation to the morphological processing. entrin time intervals. Different measur can be employed ranging from low-accuracy methods such as cards with graded lines and a ruler or gauge wires to highly accurate image-processing methods..$^{22,23}$ The evaporation behavior of soils when subject to desiccation cracking can be highly affected by the width and depth of the cracks; thus, an accurate measurement of the geotechnical parameters of soil shrinkage cracks is not easy to achieve with direct methods. A large measurement error should be expected due to the irregular shape and complex crack pattern. Desiccation cracking also occurs in the form of a random network with various widths and depths. In recent years, image-analysis techniques have been extensively used to characterize crack networks with an improved accuracy. CIF is the descriptor of the extent of desiccation racking used by many researchers. It is calculated based on the definition by $\mathrm{H}$. $\mathrm{Mi}^{24}$ and C. J. Miller et al. ${ }^{25}$ as the ratio of the area of cracks (Ac) to the total surface area (A) of a drying soil mass.

Most crack-detection algorithms using image-processing techniques are based on these two primary assumptions:

1) crack pixels can be distinguished from their surrounding area since they usually have a lower intensity value, i.e., crack pixels are usually darker than their neighborhood;

\section{TESTING PROCEDURE}

The experimental procedure consisted of two main steps:

1) soil preparation and compaction and

2) a simulation of wetting/drying cycles.

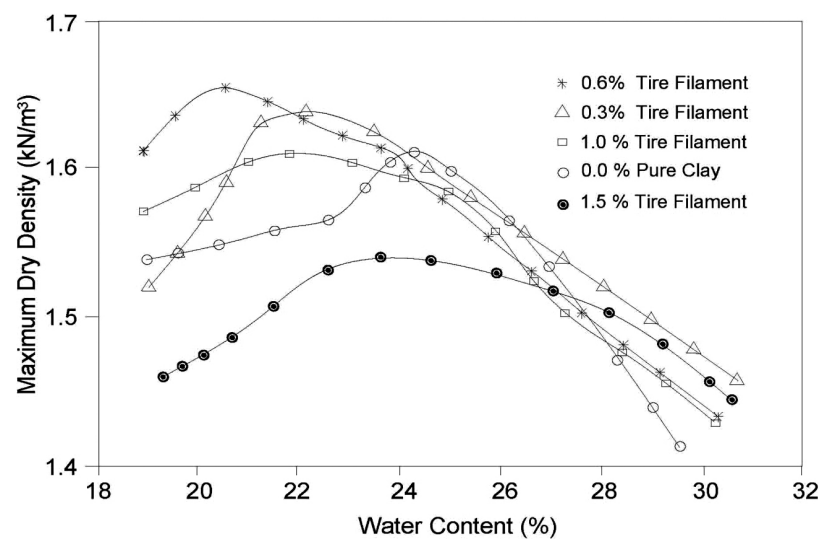

Figure 5: Compaction characteristics of mixed Avanos clay 


\section{Mixture preparation and compaction process}

The compaction of the composite soil mixtures required special attention to ensure the uniformity of density and moisture conditions throughout the testing. The installation processes were also important variables in monitoring the strength, hydraulic conductivity and crack desiccation. In this study, the composite test specimens were compacted at $3 \%$ above the optimum water content. For the tire monofilaments used as the additive to the Avanos clay, the prescribed amount of tire shreds was mixed into the air-drilled soil in small increments by hand, making sure all the tire shreds were mixed thoroughly to achieve a fairly uniform mixture, and then the required amount of water was added. Then, as mentioned above, as with the clay samples, the mixture specimens were sealed in plastic bags and allowed to hydrate for $48 \mathrm{~h}$ prior to compaction. The prepared specimens were then placed into molds. A square steel pad with an area of $25 \mathrm{~cm}^{2}$ and a weight of $4.5 \mathrm{~kg}$ under a free fall of $20 \mathrm{~cm}$ to the specimen surfaces was used to compact the specimens. Through this procedure, a series of compaction processes were performed involving 20-mm tire-shred fibers mixed with the Avanos clay. The results obtained with the standard Proctor compaction tests for the tire-shred clay composite material are presented in Figure 5.

It is quite evident from Figure 5 that the addition of tire filaments into the clay has a relative effect on the maximum dry density as well as on the optimum water content. The optimum moisture content for the soil with added tire shreds is $22-25 \%$. The maximum dry density occurred at $0.6 \%$ of the tire monofilament in the mixture. The lowest dry density was obtained at $1.5 \%$ of the added monofilament. There was no direct relationship between the tire amount and the maximum dry density.

\section{Hydraulic conductivity}

Low hydraulic conductivity is an essential characteristic when assessing the acceptability of soil and soil mixtures for containment structures such as landfill covers, bottom liners or dam cores. In general, the hydraulic behavior of fine soils is influenced by the interaction between the pore fluid and minerals. ${ }^{27}$ Therefore, the effect of tire-shred clay mixtures on the hydraulic conductivity of the clayey soils selected for the study is of primary concern and needs to be carefully evaluated. The results of the tests conducted with $6.12-\mathrm{kPa}$ and $25-\mathrm{kPa}$ consolidation pressure are given in Figure 6. As seen, at $25 \mathrm{kPa}$, the hydraulic conductivity of the mixtures was approximately $1 \times 10^{-9}$ to $3 \times 10^{-9} \mathrm{~m} / \mathrm{sec}$ for all the portions of the tire monofilaments. There is also a slight decrease in the hydraulic conductivity as the tiremonofilament content is increased from $0 \%$ to $1.0 \%$. The magnitude of the hydraulic conductivity rose with the increase in the tire-monofilament content as shown in Figure 6, revealing an approximate increase of 4 times in the hydraulic conductivity. As all the evaluated per-

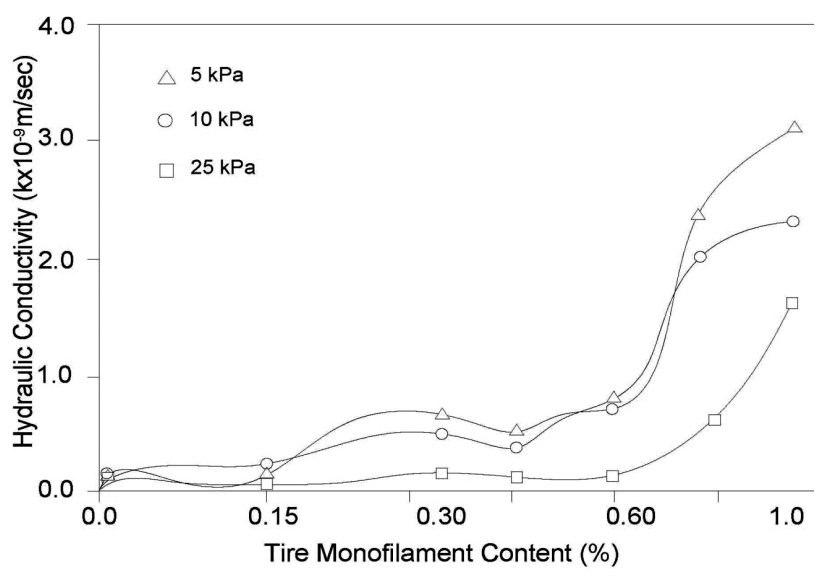

Figure 6: Hydraulic conductivity of mixed Avanos clay

meabilities were of the same order of magnitude $\left(10^{-9} \mathrm{~m} / \mathrm{s}\right)$, it can be concluded that a random tire-monofilament inclusion did not produce a significant effect on the hydraulic conductivity of the clay. This observation is in agreement with the results reported by B. A. Maher et al. ${ }^{19}$ and M. R. Abdi et al. ${ }^{28}$

\section{Wetting/drying}

Tests were conducted with mixed and compacted samples to determine the duration of drying and wetting periods. The soil samples were weighed every $12 \mathrm{~h}$. In order to determine the duration of the wetting period, two soil samples were compacted, dried for five days and then water was pounded on the top of each sample by placing the collar around the mold. Every two days, the soil specimens were removed from the mold to determine of the amount of water content at the base of the mold. After 6 days of wetting, the soil was fully saturated and therefore a 6-day period was considered to be appropriate for the wetting period. The experiments included 3 W-D cycles for the pure-Avanos-clay

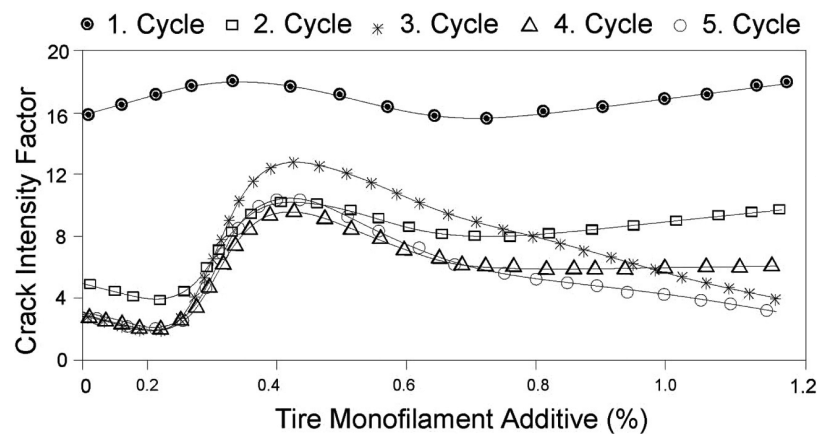

Figure 7: CIF for Avanos clay amended with tire monofilaments

Table 2: Crack reduction

\begin{tabular}{|c|c|c|c|c|c|}
\hline Fiber (\%) & Cycle 1 & Cycle 2 & Cycle 3 & Cycle 4 & Cycle 5 \\
\hline 0.00 & 68.9 & - & - & - & - \\
\hline 0.15 & 75.7 & 3.6 & 9.1 & 3.8 & 5.4 \\
\hline 0.30 & 53.9 & 55.4 & 96.8 & 64.8 & 72.4 \\
\hline 0.60 & 70.4 & 44.7 & 73.1 & 41.3 & 39.7 \\
\hline 1.00 & 68.9 & 46.5 & 19.1 & 30.6 & 7.1 \\
\hline
\end{tabular}




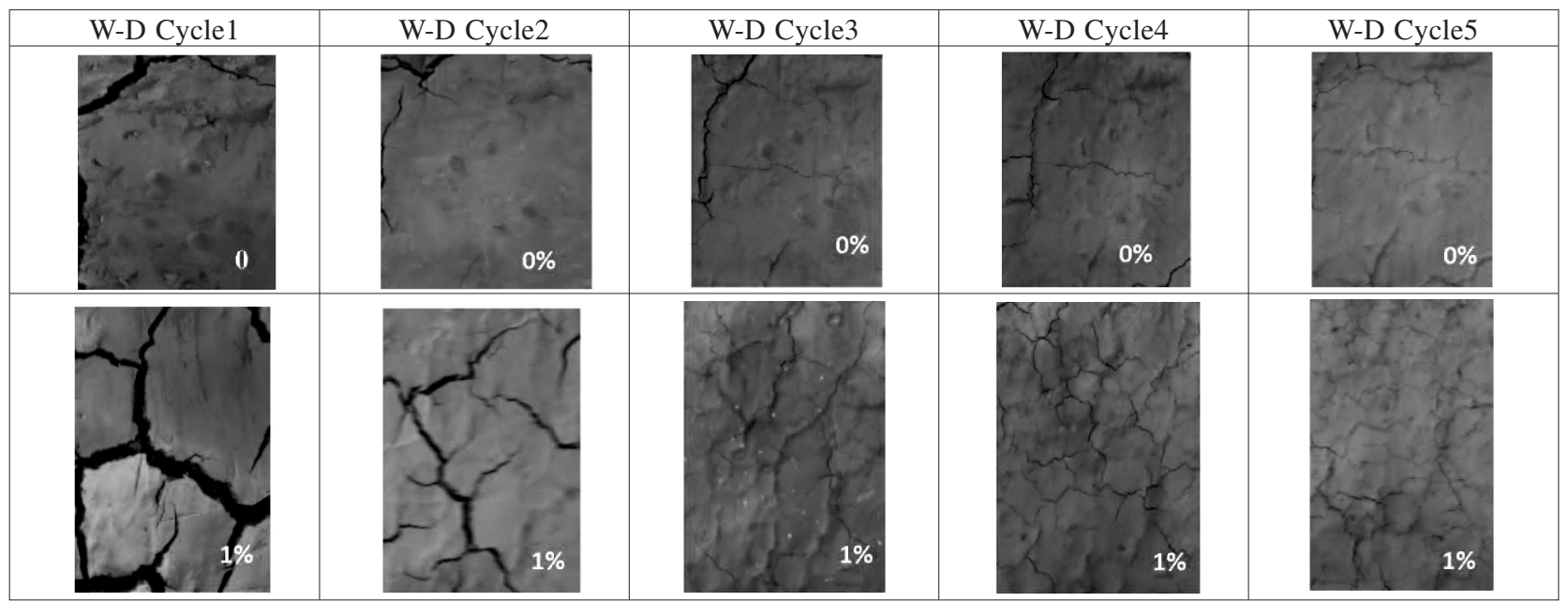

Figure 8: Photographs of desiccated samples

samples, while the mixed samples of the amended soils required between $1-3 \mathrm{~W}-\mathrm{D}$ cycles.

\section{Desiccation test results}

The desiccation tests included five cycles of wetting/drying periods. Images of the desiccated samples were taken four times a day and at the end of each drying period. The tests were performed on replicate samples of the Avanos clay with a specific portion of the tire monofilaments to check the repeatability of the results. To verify the effect of the tire-monofilament content as a measure of reducing cracks, the Avanos clay was mixed with amounts of $(0.15,0.30,0.60$ and 1.0$) \%$ filaments. Each mixture was analyzed separately and close-range images were being captured until the desiccation process was completely finished. Based on the threshold images, CIF was calculated through the ratio of the surface area of the cracks (the white area) and the total surface area of the images (A). The variation of CIF during the wetting/drying cycles is given in Figure 7.

As shown in Figure 7, in the first desiccation process, the filament additive has almost no effect on the cracking formation. However, after the first cycle, a distinctive effect of the tire monofilaments on the cracking mechanism is evident. The distribution shape of the gradient indicates an ' $S$ ' curve and the minimum crack-intensity factor occurs when $0.3 \%$ of the tire monofilaments was added to the clay. The percentage of the crack reduction in the specimens is shown in Table 2. It can also be clearly seen that for the Avanos clay, the most effective percentage of the tire shreds is $0.3 \%$. The desiccation process, the patterns of the crack mechanism and additive percentages are shown in Figure 8.

Figure 8 presents typical final (the end of the $6^{\text {th }}$ day) crack openings of tire-monofilament-reinforced clay specimens with different fiber contents. It can be seen that the morphology of the crack patterns was significantly influenced by the inclusion of the fibers and W-D cycles. In particular, the fiber content increases the number of wide cracks and the number of fine cracks.
Furthermore, the crack networks gradually change from an apparent regular structure to an irregular structure and many dead-end cracks or single cracks that do not intersect other cracks are identified. This observation is in agreement with the results reported by $\mathrm{T}$. Chaosheng et al. ${ }^{29}$; however, the propagation of shrinkage cracks cannot be categorized as purely orthogonal or non-orthogonal patterns. According to J. K. Kodikara et al. ${ }^{30}$ and J. $\mathrm{H}$. Li et al. ${ }^{31}$, generally, the final stage of the crack patterns is basically a mixture of orthogonal, non-orthogonal, simultaneous and sequential cracks. On the images from Figure 10, it is interesting to observe that all our test specimens produced predominantly sequential, orthogonal crack patterns, leading to a subdivision of the crack area into smaller cells.

\section{CONCLUSION}

Desiccation is a set of processes that includes drying, shrinkage and cracking. The most important process taking place in earth-based embankments such as dam cores, dikes or landfill liners, is the cracking of the clay material. The process of predicting and, thus, preventing the cracking of clay is extremely complex because of many degrees of freedom and the effects of various parameters on the suction forces on the surface of clay. In order to understand this complex behavior of the cracking mechanism of the Avanos clay, experiments with different tire-monofilament mixtures were carried out. The desiccation and cracking behaviors of the clay/tire-monofilament mixtures with the optimum water content were investigated through five wetting/drying (W-D) cycles. A quantitative evaluation of the crack mechanism was determined using the image analysis and time-interval close-range photography. Based on the experimental studies, the following conclusions can be drawn;

- Multiple wetting/drying cycles resulted in changes in the clay structure and cracking characteristics. 
- The minimum density and optimum water content were reduced by adding tire monofilaments to the clay.

- There was no remarkable effect on the hydraulic conductivity when the amount of tire monofilaments in the clay was increased.

- According to the CIF results, a $0.2-0.3 \%$ tire-monofilament content considerably reduced the extent of cracks and shrinkage when added to the Avanos clay.

- The optimum tire-monofilament content was $0.2-0.3 \%$, resulting in the maximum crack reduction, minimum shrinkage and an acceptable hydraulic conductivity within the range of mixing workability.

- Image processing provided useful information on the geometric characteristics of the crack patterns.

\section{REFERENCES}

${ }^{1}$ D. Lomeling, M. C. Kenyi, M. A. Lodiong, M. S. Kenyi, G. M. Silvestro, J. L. Yieb, Characterizing Dessication Cracking of a Remolded Clay (Eutric Vertisol) Using the Fractal Dimension Approach, Open Journal of Soil Science, 6 (2016) 04, 68-80, doi:10.4236/ojss.2016.64008

${ }^{2}$ M. H. Maher, D. H. Gray, Static response of sands reinforced with randomly distributed fibers, Journal of Geotechnical Engineering, 116 (1990) 11, 1661-1677, doi:10.1061/(ASCE)0733-9410(1990) 116:11(1661)

${ }^{3}$ N. Yesiller, C. J. Miller, G. Inci, K. Yaldo, Desiccation and cracking behavior of three compacted landfill liner soils, Engineering Geology, 57 (2000) 1, 105-121, doi:10.1016/S0013-7952(00)00022-3

${ }^{4}$ R. D. Holtz, W. D. Kovacs, An Introduction to Geotechnical Engineering, Prentice-Hall, Upper Saddle River, New Jersey, USA, 1981

${ }^{5}$ M. A. Kaya, G. Özürlan, E. Şengül, Delineation of soil and groundwater contamination using geophysical methods at a waste disposal site in Çanakkale, Turkey, Environmental Monitoring and Assessment, 135 (2007) 1, 441-446, doi:10.1007/s10661-007-9662-x

${ }^{6}$ D. E. Daniel, Y. K. Wu, Compacted clay liners and covers for arid sites, Journal of Geotechnical Engineering, 119 (1993) 2, 223-237, doi:10.1061/(ASCE)0733-9410(1993)119:2(223)

C. H. Benson, S. R. Meer, Relative abundance of monovalent and divalent cations and the impact of desiccation on geosynthetic clay liners, Journal of Geotechnical and Geoenvironmental Engineering, 135 (2009) 3, 349-358, doi:10.1061/(ASCE)1090-0241(2009) 135:3(349)

${ }^{8}$ F. Mazzieri, Impact of desiccation and cation exchange on the hydraulic conductivity of factory-prehydrated GCLs, Geo-Frontiers 2011: Advances in Geotechnical Engineering, (2011), 976-985, doi:10.1061/41165(397)100

${ }^{9}$ B. A. Albrecht, C. H. Benson, Effect of desiccation on compacted natural clays, Journal of Geotechnical and Geoenvironmental Engineering, 127 (2001) 1, 67-75, doi:10.1061/(ASCE)10900241(2001)127:1(67)

${ }^{10}$ S. S. Boynton, D. E. Daniel, Hydraulic conductivity tests on compacted clay, Journal of Geotechnical Engineering, 111 (1985) 4, 465-478, doi:10.1061/(ASCE)0733-9410(1985)111:4(465)

${ }^{11}$ K. J. Witt, R. M. Zeh, Cracks due to desiccation in cover lining systems phenomena and design strategy, International Workshop LIRIGM, Grenoble University, France, 2005, doi:10.1016/j.enggeo. 2008.05.005

${ }^{12}$ H. Krisdani, H. Rahardjo, E. C. Leong, Effects of different drying rates on shrinkage characteristics of a residual soil and soil mixtures, Engineering Geology, 102 (2008) 1, 31-37, doi:10.1016/j.enggeo. 2008.07.003
${ }^{13}$ G. H. Omidi, Desiccation shrinkage and cracking in soil liner, Ph.D. Dissertation, Texas A \& M University, College Station, TX, 1993

${ }^{14}$ K. J. Osinubi, A. O. Eberemu, Desiccation induced shrinkage of compacted lateritic soil treated with blast furnace slag, Geotechnical and Geological Engineering, 28 (2010) 5, 537-547, doi:10.1007/ s10706-010-9308-6

${ }^{15}$ T. Harianto, S. Hayashi, Y. J. Du, D. Suetsugu, Effects of fiber additives on the desiccation crack behavior of the compacted Akaboku soil as a material for landfill cover barrier, Water, Air, and Soil Pollution, 194 (2008) 1, 141-149, doi:10.1007/s11270-0089703-2.

${ }^{16}$ N. Talluri, V. Puljan, T. Manosuthikij, A. J. Puppala, S. Saride, Prediction of swell-shrink movements of pavement infrastructure, Geo-Frontiers Congress, Dallas, Texas, 2011, doi:10.1061/ 41165(397)280

${ }^{17}$ Y. Guney, D. Sari, M. Cetin, M. Tuncan, Impact of cyclic wetting-drying on swelling behavior of lime-stabilized soil, Building and Environment, 42 (2007) 2, 681-688, doi:10.1016/j.buildenv. 2005.10.035

${ }^{18}$ F. Zangl, W. J. Likos, Alternative methods for wet-dry cycling of geosynthetic clay liners, Journal of Geotechnical and Geoenvironmental Engineering, 142 (2016) 11, 04016063, doi:10.1061/ (ASCE)GT.1943-5606.0001508

${ }^{19}$ B. A. Maher, R. Thompson, L. P. Zhou, Spatial and temporal reconstructions of changes in the Asian palaeomonsoon: A new mineral magnetic approach, Earth and Planetary Science Letters, 125 (1994) 1, 461-471, doi:10.1016/0012-821X(94)90232-1

${ }^{20}$ M. S. Nataraj, K. L. McManis, Strength and deformation properties of soils reinforced with fibrillated fibers, Geosynthetics International, 4 (1997) 1, 65-79, doi:10.1680/gein.4.0089

${ }^{21}$ C. S. Tang, B. Shi, Y. J. Cui, C. Liu, K. Gu, Desiccation cracking behavior of polypropylene fiber-reinforced clayey soil, Canadian Geotechnical Journal, 49 (2012) 9, 1088-1101, doi:10.1139/ t2012-067

${ }^{22}$ L. Barazzetti, M. Scaioni, Crack measurement: Development, testing and applications of an automatic image-based algorithm, ISPRS Journal of Photogrammetry and Remote Sensing, 64 (2009) 3, 285-296, doi:10.1016/j.isprsjprs.2009.02.004

${ }^{23}$ J. H. Kleppe, R. E. Olson, Desiccation cracking of soil barriers, Hydraulic barriers in soil and rock, ASTM International, 1985, doi:10.1520/STP34583S

${ }^{24} \mathrm{H}$. Mi, Kinematic wave formulation for flow through macroporous soil, Ph.D. Thesis, Department of Civil and Environmental Engineering, Wayne State University, Detroit, MI, 1995

${ }^{25}$ C. J. Miller, H. Mi, N. Yesiller, Experimental analysis of desiccation crack propagation in clay liners, Journal of the American Water Resources Association, 34 (1998) 3, 677, doi:10.1111/j.17521688.1998.tb00964.X

${ }^{26}$ Y. C. Tsai, V. Kaul, R. M. Mersereau, Critical assessment of pavement distress segmentation methods, Journal of Transportation Engineering, 136 (2009) 1, 11-19, doi:10.1061/(ASCE)TE.19435436.0000051

${ }^{27}$ J. He, Y. Wang, Y. Li, X. C. Ruan, Effects of leachate infiltration and desiccation cracks on hydraulic conductivity of compacted clay, Water Science and Engineering, 8 (2015) 2, 151-157, doi:10.1016/ j.wse.2015.04.004

${ }^{28}$ M. R. Abdi, A. Parsapajouh, M. A. Arjomand, Effects of random fiber inclusion on consolidation, hydraulic conductivity, swelling, shrinkage limit and desiccation cracking of clays, International Journal of Civil Engineering, 6 (2008) 4, 284-292

${ }^{29}$ T. Chaosheng, S. Bin, L. Chun, Study on desiccation cracking behaviour of expansive soil, Journal of Engineering Geology, 20 (2012) 5, 663-673

${ }^{30}$ J. K. Kodikara, S. L. Barbour, D. G. Fredlund, Desiccation cracking of soil layers, Proceedings of the Asian Conference on Unsaturated Soils, Unsaturated Soils for Asia, 2000, 139 
N. U. TERZI et al.: EFFECTS OF TIRE CHIPS ON THE SHRINKAGE AND CRACKING ...

${ }^{31}$ J. H. Li, L. M. Zhang, Y. Wang, D. G. Fredlund, Permeability tensor and representative elementary volume of saturated cracked soil, Canadian Geotechnical Journal, 46 (2009) 8, 928-942, doi:10.1139/ T09-037 